\title{
INTEGRASI FOTO UDARA DAN SISTEM INFORMASI GEOGRAFIS UNTUK EVALUASI PENENTUAN LETAK BANGUNAN CANDI DI WILAYAH PRAMBANAN, KLATEN, JAWA TENGAH DAN DAERAH ISTIMEWA YOGYAKARTA
}

\author{
Andi Putranto ${ }^{1}$, Sutikno ${ }^{2}$, dan Suharyadi ${ }^{3}$
}

Fakultas Geografi, Universitas Gadjah Mada, Yogyakarta, Indonesia ${ }^{1,2,3}$ andiputrantogeo@gmail.com

Diterima : Juni 2014 ; Direvisi : Agustus 2014.; Dipubikasikan: 31 Maret 2015

\begin{abstract}
ABSTRAK Sebagai bangunan keagamaan, bangunan candi didirikan atau dibangun berdasarkan syarat tertentu. Dikenal beberapa kitab pedoman pembangunan candi seperti Manasara, Silpasastra, Vastupurusa, Kashyapasilpa. Pedoman pembangunan candi tersebut tidak hanya berlaku di India saja tetapi juga di Indonesia dan begitu juga di wilayah Prambanan. Lahan yang sesuai adalah lahan yang subur, datar, jenis tanah yang baik, permeabilitas baik, tidak mengandung gas atau racun, serta mudah memperoleh air. Kesesuaian lahan merupakan tujuan utama dari penelitian ini. Penelitian dilakukan terhadap lahan di wilayah Prambanan meliputi Kecamatan Kalasan dan Prambanan Kabupaten Sleman, DIY dan Kecamatan Prambanan, Kabupaten Klaten Jawa Tengah. Digunakan data foto udara hitam putih skala 1:20.000 liputan wilayah Yogyakarta tahun perekaman 2001. Dari foto udara akan dilakukan interpretasi parameter fisik lahan yaitu bentuklahan dan penggunaan lahan. Parameter lainnya diperoleh dari data sekunder hasil penelitian yang telah dilakukan. Dilakukan interpretasi, digitasi, overlay analisis dan penilaian terhadap parameter fisik lahan dengan bantuan perangkat SIG dan diperoleh kelas kesesuaian lahan untuk bangunan candi. Diperoleh tiga kelas kesesuaian lahan untuk bangunan candi yaitu kelas S1 (Baik), S2 (Sedang) dan S3 (Buruk). Dari 11 bangunan candi terdapat sembilan candi yang terletak di lahan kelas S1 (Baik), dua candi di lahan kelas S2 (Sedang) dan tidak ada candi yang terletak di lahan kelas S3 (Buruk). Bangunan candi yang didirikan dengan persyaratan lahan secara konseptual dan tradisional berdasarkan kitab ternyata sesuai dengan kriteria kesesuaian lahan dalam pengetahuan modern. Integrasi antara data penginderaan jauh (foto udara) dan perangkat analisis SIG (ArcView) dapat digunakan untuk menyadap informasi parameter fisik lahan untuk memperoleh kelas kesesuaian lahan untuk bangunan candi di wilayah Prambanan.
\end{abstract}

Kata kunci: candi; bangunan; lahan; kesesuaian lahan; penginderaan jauh; SIG.

ABSTRACT As a religious building, the temple was founded or constructed based on certain conditions. Known some as the book of temple construction guidelines as Manasara, Silpasastra, Vastupurusa, Kashyapasilpa. Temple construction guidelines is not only apply in India, but also in Indonesia and so also in the Prambanan. Suitable land is fertile land, flat, kind of good soil, good permeability, contains no gas or toxic and easy to get water. Land suitability is the main of this research. Research carried out on Prambanan area includes the Kalasan and Prambanan sub-district Sleman Regency, Yogyakarta and Prambanan sub-district, Klaten regency, Central Java. Data was used panchromatic aerial photographs scale of 1: 20,000 coverage of Yogyakarta recording year 2001. From the aerial photo will intrepret using physical parameter, namely landforms and land use. Other parameters obtaine from secondary data from results of previous research. Interpretation, digitization, overlay analysis and assessment of the physical parameters use GIS tool and obtaine land suitability category for temple. There are three category of land suitability for temple is S1 (Good), S2 (moderate) and $S 3$ (Bad). From the 11 temple, there are nine temples located in the S1 (Good), two temples in S2 (moderate) and no temples in S3(Poor). The temple building was established with the requirements land in conceptual and traditional based on the book with the criteria of land suitability in modern science. The integration between remote sensing data (aerial photos) and analysis tools GIS (ArcView) can be used to extract physical parameters information to obtain land suitability categories in Prambanan Temple building in the region.

Key words: temple; building; land; land suitability; remote sensing; SIG. 


\section{PENDAHULUAN}

Wilayah Prambanan merupakan suatu wilayah yang kaya akan situs-situs arkeologi baik yang sudah ditemukan maupun yang masih berada di bawah permukaan tanah. Situs-situs tersebut didominasi oleh situs-situs percandian. Adapun yang termasuk dalam situs yang berupa kelompok percandian adalah kompleks Candi Siwa atau dikenal masyarakat sebagai Candi Rara Jonggrang. Kompleks Candi Sewu, kompleks Candi Plaosan, kompleks Candi Sambisari, kompleks Candi Kedulan, kompleks Candi Ijo, dan kompleks Candi Ratu Baka

Bangunan-bangunan candi tersebut terletak dalam wilayah yang cukup luas dalam satuan bentuklahan yang tidak sama satu dengan lainnya. Kompleks Candi Ratu Baka, kompleks Candi Barong, kompleks Candi Ijo, kompleks Stupa Dawangsari terletak pada satuan bentuklahan perbukitan struktural. Kompleks Candi Rara Jonggrang, kompleks Candi Sambisari, kompleks Candi Kedulan, kompleks Candi Sewu, kompleks Candi Plaosan, Candi Kalasan, Candi Sari, Candi Lumbung, Candi Bubrah terletak pada dataran rendah pada bentuklahan dataran alluvial (Mundardjito, 1993). Bangunan-bangunan candi yang terletak di wilayah Prambanan dibangun pada kurun waktu antara abad VIII-X Masehi (Kempers, 1959; Mundardjito,1993).

Hampir seluruh bangunan candi yang terletak di wilayah Prambanan pada saat ditemukan kembali berada dalam kondisi runtuh atau rusak. Kondisi ini menimbulkan pertanyaan hingga saat ini yaitu mengenai penyebab keruntuhan bangunan candi tersebut. Kondisi bangunan candi yang hampir seluruhnya telah mengalami keruntuhan pada saat ditemukan dapat disebabkan oleh banyak faktor.

Faktor konstruksi bangunan candi sendiri dapat menjadi penyebab runtuhnya bangunan tersebut, mengingat beberapa candi telah mengalami perubahan pasca pembangunan awalnya (Kempers, 1959). Selain itu faktor ketidaksesuaian lahan tempat berdirinya candi juga dapat menjadi penyebab terjadinya keruntuhan bangunan meskipun terjadi dalam jangka waktu yang lama sejak dibangun, selain faktor lainnya seperti adanya bencana alam, gempa tektonik, letusan gunung berapi. Dampak dari adanya ketidaksesuaian lahan terhadap bangunan candi merupakan ancaman tersendiri terhadap kelestarian situs-situs arkeologi di berbagai wilayah di Indonesia pada umumnya, serta di wilayah Prambanan pada khususnya. Pengertian kesesuaian lahan dalam penelitian ini adalah kecocokan lahan dimana situs-situs arkeologi dalam hal ini berupa bangunan candi didirikan diatasnya dan tingkat pengelolaannya berkaitan dengan nilai kesesuaian yang diukur (Hardjowigeno, 2011).
Agama Hindu dan Budha mengenal adanya kitab pedoman untuk pendirian bangunan suci keagamaan termasuk bangunan candi. Kitab seperti ManasaraSilpasastra, Vastupurusa, Kashyapasilpa memberikan petunjuk mengenai prinsip pendirian bangunan suci candi mulai dari desain atau lay out, proses pemilihan lahan, materi atau bahan bangunan, hingga pendiriannya (Acarya, 1934; Banerjee, 1993; Slackzka, 2007; Vardia, 2008; Degroot, 2009). Pedoman tersebut disusun bertujuan agar bangunan candi berfungsi sebagai bangunan suci dan diselesaikan dalam bentuk dan kualitas yang sebaik-baiknya.

Pemanfaatan penginderaan jauh menggunakan foto udara untuk kajian di bidang arkeologi adalah pendekatan yang dapat diajukan untuk menyadap informasi karakteristik lahan. Karakter dari foto udara terkait dalam peliputan obyek di muka bumi, juga sangat memungkinkan melihat hubungan spasial antara situs dengan lingkungan di sekitarnya. Melalui foto udara dapat diketahui letak situs pada suatu lahan tertentu yang didalamnya terdapat karakteristik lahan berupa bentuklahan, lereng, penggunaan lahan, hidrologi, tanah, batuan.

Integrasi foto udara dengan perangkat SIG mampu untuk melakukan penilaian untuk memperoleh kesesuaian lahan untuk penentuan letak pendirian bangunan candi. Sistem Informasi Geografis mampu melakukan analisis spasial yang menjangkau hubungan antar variabel yang terkait dengan karakteristik sekaligus melakukan penilaian karakteristik lahan yang dapat dijadikan dasar untuk menyusun kelas kesesuaian lahan untuk bangunan candi.

Penginderaan jauh adalah suatu ilmu dan seni untuk memperoleh informasi tentang suatu obyek, daerah ataupun fenomena melalui analisis data yang diperoleh dari suatu alat tanpa melakukan kontak langsung dengan obyek, daerah, atau fenomena yang dikaji (Lillesand \& Kiefer, 1998). Berdasarkan atas sumber tenaga yang digunakan, sistem penginderaan jauh dapat dibedakan menjadi penginderaan jauh sistem aktif dan sistem pasif. Penginderaan jauh sistem aktif menggunakan sumber tenaga yang dipancarkan oleh sensor dan dipantulkan kembali oleh obyek untuk kemudian ditangkap kembali oleh sensor. Sistem penginderaan jauh pasif menggunakan sumber tenaga berupa sinar matahari yang dipantulkan oleh obyek untuk kemudian ditangkap oleh sensor. Sistem penginderaan jauh dengan foto udara termasuk dalam penginderaan jauh sistem pasif dengan menggunakan panjang gelombang tampak (visible) (Lillesand \& Kiefer, 1998).

Candi merupakan bagian dari benda cagar budaya baik berupa kesatuan ataupun kelompok. Secara 
arkeologis candi merupakan sebutan untuk bangunan/monumen keagamaan yang digunakan sebagai tempat pemujaan yang bercirikan agama Hindu dan Budha. Proses pembangunan candi berkaitan erat dengan kondisi lahan dimana candi tersebut akan dibangun. Sebelum candi dibangun, terlebih dahulu dilakukan proses pemilihan calon lokasi, diikuti dengan pengukuran lahan terkait dengan peletakan pondasi candi. Lahan yang telah terpilih sebagai calon lokasi kemudian diuji kelayakannya dengan cara dibajak, dialiri/digenangi air, ditanami biji tanaman. Proses ini dilakukan berulang, kemudian biji yang ditanam ditunggu hingga tumbuh. Proses ini dilakukan untuk menguji tingkat kesuburan tanah tersebut. Asumsi yang dimunculkan adalah tanah yang subur adalah tanah yang terbaik sebagai lokasi untuk didirikan candi (Acharya, 1934; Soekmono, 1995).

Lahan merupakan lingkungan fisik yang didalamnya terdapat parameter topografi, tanah, batuan, hidrologi dimana parameter tersebut berpengaruh terhadap potensi penggunaannya. Lahan memiliki karakteristik yang dapat diukur atau diprakirakan besarnya. Dalam pemanfaatannya lahan memiliki kualitas lahan yang mempunyai pengaruh nyata terhadap kesesuaiannya untuk penggunaan tertentu (Hardjowigeno, 2011). Lahan yang dimaksud dalam penelitian ini adalah lingkungan fisik yang di atasnya terdapat bangunan candi.

Foto udara telah mampu dimanfaatkan untuk berbagai keperluan. Foto udara berisi hasil rekaman rinci tentang kenampakan obyek di permukaan bumi pada saat pemotretan. Hasil rekaman tersebut menyajikan tujuh karakter dasar permukaan bumi yang dapat diamati melalui foto udara. Ketujuh karakter dasar tersebut adalah: 1). Bentuk, 2). Ukuran, 3). Pola, 4). Bayangan, 5). Rona, 6). Tekstur, 7). Situs (Lillesand \& Kiefer, 1998).

Sistem Informasi Geografis atau SIG secara ringkas dapat didefinisikan sebagai suatu teknologi sistem informasi (berbasis komputer) yang digunakan untuk memproses, menyusun, menyimpan, memanipulasi, dan menyajikan data spasial (yang disimpan dalam basis data) untuk berbagai macam aplikasi. SIG juga merupakan suatu kombinasi antara manusia yang terlatih, data spasial dan deskriptif, metode analisis, perangkat lunak dan keras, yang terorganisir untuk menjalankan, mengatur, dan memberikan informasi melalui presentasi geografis (Zieler, 1999). SIG digunakan sebagai perangkat untuk memproses, menyusun, menyimpan, memanipulasi dan menyajikan data spasial berupa peta kelas kesesuaian lahan untuk bangunan candi.
Berdasarkan telaah pustaka yang terkait dengan pembangunan bangunan candi di atas, maka dapat dapat dirangkum sebagai berikut: 1) sifat fisik tanah berhubungan dengan kesuburan tanah dan permeabilitas tanah ; 2) jenis batuan yang berhubungan dengan sumber air dan kedalaman air tanah; 3) topografi, morfologi berhubungan dengan kontur lahan. Bentuklahan berasosiasi dengan keberadaan gas di dalam tanah yang dapat dijumpai pada daerah sesar atau berasosiasi dengan gunungapi. Penggunaan lahan berhubungan dengan sumber daya lahan untuk mendukung keberlangsungan bangunan candi dalam fungsinya sebagai bangunan keagamaan yang harus dipelihara. Penggambaran tersebut di atas menjadi dasar perolehan data yang akan diinterpretasi dari data foto udara maupun diperoleh dari data sekunder yang berasal dari peta tematik dan hasil penelitian lainnya.

Perlu dilakukan penilaian terhadap karakteristik lahan dengan memanfaatkan teknik penginderaan jauh menggunakan data foto udara dan penilaian dan pengolahan menggunakan SIG agar dapat diperoleh kelas kesesuaian lahan untuk bangunan candi. Permasalahan penelitian yang akan dijawab adalah : (1) apakah foto udara hitam putih dapat digunakan untuk memperoleh informasi karakteristik lahan di sekitar bangunan candi?; (2) sejauh manakah foto udara dan Sistem Informasi Geografis dapat digunakan dalam pembuatan kelas kesesuaian lahan untuk bangunan candi di wilayah Prambanan?; (3) bagaimanakah kelas kesesuaian lahan untuk bangunan candi di wilayah Prambanan?. Tujuan penelitian ini adalah untuk: (1) mempelajari karakteristik lahan di wilayah Prambanan melalui interpretasi foto udara hitam putih; (2) mengetahui kemampuan foto udara dan SIG dalam penilaian karakteristik lahan dan pembuatan kelas kesesuaian lahan; (3) membuat kelas kesesuaian lahan untuk bangunan candi di wilayah Prambanan berdasarkan penilaian terhadap karakteristik lahan sehingga dapat diperoleh gambaran mengenai kualitas lahan tempat bangunan candi dibangun.

\section{METODE PENELITIAN}

Metode penelitian yang dilaksanakan meliputi bahan dan peralatan yang digunakan, serta tahapan atau jalannya penelitian yang dijelaskan sebagai berikut:

1. Dilakukan pengumpulan bahan pustaka yang terkait dengan tema penelitian seperti baik berupa teori, konsep maupun hasil-hasil penelitian yang terkait. Perolehan data foto udara hitam putih, peta dasar, dan peta tematik yang terkait dengan penelitian lahan merupakan tahap awal yang dilaksanakan dalam penelitian ini. 
2. Metode yang digunakan dalam penelitian ini adalah teknik penginderaan jauh melalui interpretasi foto udara hitam putih skala 1:20.000 wilayah Yogyakarta tahun liputan 2001. Interpretasi dilakukan secara on screen selanjutnya dilakukan digitasi secara bersamaan (on screen digitatation). Parameter fisik lahan yang diinterpretasi adalah bentuklahan, jarak candi dengan sungai dan penggunaan lahan, sedangkan parameter lainnya diperoleh dari peta tematik hasil penelitian terkait lahan di wilayah yang sama.

3. Hasil interpretasi dari foto udara kemudian dilakukan pengecekan lapangan untuk memperoleh tingkat akurasi yang memadai. Selanjutnya parameter fisik lahan hasil interpretasi dan hasil digitasi peta tematik dilakukan proses overlay analisis dengan metode analisis kuantitatif berjenjang dengan faktor pembobot melalui bantuan perangkat SIG untuk memperoleh peta satuan lahan. Dalam metode ini tiap parameter fisik lahan yang menjadi karakteristik lahan diberikan harkat dan pemberian faktor pembobot untuk kemudian dilakukan proses identify menggunakan perangkat SIG untuk diperoleh kelas kesesuaian lahan untuk bangunan candi.

\section{HASIL DAN PEMBAHASAN}

Hasil interpretasi, analisis dan digitasi foto udara maupun sumber sekunder adalah peta satuan yang terdiri atas parameter bentuklahan, penggunaan lahan, lereng, batuan, jenis tanah, permeabilitas tanah, dan kedalaman air tanah. Masing-masing parameter lahan tersebut kemudian diberi harkat atau skor seperti disajikan dalam Tabel 1, 2, 3, 4, 5, 6, 7, dan 8. Tiap parameter memiliki bobot yang berkisar antara 1-3 yang akan digunakan sebagai faktor perkalian dari hakat yang diberikan seperti pada Tabel 9. Setelah itu ketujuh satuan peta ini dengan perangkat SIG (ArcView) dilakukan overlay analisis dengan menggunakan fungsi identity.

Urutan bobot dari tiap parameter diatas menunjukkan faktor yang paling utama berpengaruh terhadap kriteria kesesuaian lahan untuk bangunan candi. Faktor atau parameter bentuklahan, jarak terhadap sungai, lereng, dan batuan (3) adalah faktor paling utama dengan. Selanjutnya diikuti parameter penggunaan lahan, jenis tanah, dan permeabilitas tanah (2) dan yang paling kecil adalah parameter kedalaman air tanah (1). Setelah proses identity ini selesai maka akan dilakukan pembuatan skor akhir dengan memanfaatkan fasilitas field calculator pada perangkat SIG (ArcView) yang akan menghasilkan kelas kesesuaian lahan dengan pembagian kelas intervalnya tampak pada Tabel 10 .

Setelah peta kesesuaian lahan untuk bangunan candi dapat dibuat kemudian dilakukan overlay dengan data keletakan bangunan candi yang ada di wilayah Prambanan. Hasilnya menunjukkan bahwa dari sebelas bangunan candi yang ada, terdapat sembilan candi yang menempati lahan dengan kelas kesesuaian S1 (Baik), dua candi menempati lahan dengan kelas kesesuaian S2 (Sedang) dan tidak ada candi yang menempati lahan dengan kelas kesesuaian S3 (Buruk).

Tabel 1. Harkat Bentuklahan

\begin{tabular}{clc}
\hline No & Bentuklahan & Harkat \\
\hline 1 & Dataran aluvial & 5 \\
& Cekungan fluvial & 4 \\
& Rawa belakang; Perbukitan Denudasional & 3 \\
3 & terkikis ringan. & \\
& Dataran banjir; Rawa air tawar; Perbukitan & 2 \\
4 & Denudasional terkikis sedang; Perbukitan & \\
& karst. & \\
5 & Perbukitan Denudasional terkikis kuat & 1 \\
\hline
\end{tabular}

Tabel 2. Harkat Penggunaan Lahan

\begin{tabular}{clc}
\hline No & Jenis Penggunaan Lahan & Harkat \\
\hline 1 & Dataran aluvial & 5 \\
2 & Cekungan fluvial & 4 \\
& Rawa belakang; Perbukitan Denudasional & 3 \\
3 & terkikis ringan. & \\
& Dataran banjir; Rawa air tawar; Perbukitan & 2 \\
4 & Denudasional terkikis sedang; Perbukitan & \\
& karst. & 1 \\
5 & Perbukitan Denudasional terkikis kuat & \\
\hline
\end{tabular}

Tabel 3. Harkat Jarak Candi terhadap Sungai

\begin{tabular}{clc}
\hline No & Jarak Sungai & Harkat \\
\hline 1 & $<200$ meter & 5 \\
2 & $201-400$ meter & 4 \\
3 & $401-600$ meter & 3 \\
4 & $601-800$ meter & 2 \\
\hline
\end{tabular}

Tabel 4. Harkat Lereng

\begin{tabular}{cllc}
\hline No & Kelas Lereng & Kemiringan & Harkat \\
\hline 1 & Datar atau hampir datar & $0-2 \%$ & 5 \\
2 & Agak miring & $3-7 \%$ & 4 \\
3 & Miring & $8-13 \%$ & 3 \\
4 & Agak Curam & $14-20 \%$ & 2 \\
5 & Curam & $21-55 \%$ & 1 \\
6 & Sangat Curam & $>56 \%$ & 1 \\
\hline
\end{tabular}


Tabel 5. Harkat Litologi

\begin{tabular}{cllc}
\hline No & Kode & Jenis Batuan & Harkat \\
\hline 1 & Qa & Aluvium di dataran aluvial & 5 \\
& Qmi & Breksi volkanikelastik & \\
2 & Tmoa & Batupasir volkanikelastik & 4 \\
3 & & Breksi volkanikelastik & 3 \\
& a & Andesit & \\
& da & Dasit & 2 \\
4 & Qc & Koluvium & \\
& Tmps & Batuan volkanikelastik \\
& & gampingan \\
5 & Teon & Batuan silisikelastik (Batupasir- & 1 \\
& & Batulempung) & \\
\hline
\end{tabular}

Tabel 6. Harkat Tanah

\begin{tabular}{clc}
\hline No & Jenis Tanah & Harkat \\
\hline 1 & Regosol, litosol, & 5 \\
2 & Grumosol & 1 \\
\hline
\end{tabular}

Tabel 7. Harkat Permeabilitas Tanah

\begin{tabular}{clc}
\hline No & Permeabilitas tanah & Harkat \\
\hline 1 & Permeabilitas Sangat Lambat & 1 \\
2 & Permeabilitas Lambat & 2 \\
3 & Permeabilitas Sedang & 5 \\
4 & Permeabilitas Cepat & 2 \\
5 & Permeabilitas Sangat Cepat & 1 \\
\hline
\end{tabular}

Tabel 8. Harkat Kedalaman Airtanah

\begin{tabular}{clc}
\hline No & Airtanah & Harkat \\
\hline 1 & Air Tanah Sangat Dangkal & 1 \\
2 & Air Tanah Dangkal & 3 \\
3 & Air Tanah Sedang & 5 \\
4 & Air Tanah Dalam & 2 \\
5 & Air Tanah Sangat Dalam (langka) & 1 \\
\hline
\end{tabular}

Tabel 9. Faktor Pembobot

\begin{tabular}{clc}
\hline No & Karakteristik lahan & Faktor Pembobot \\
\hline 1 & Bentuklahan & 3 \\
2 & Lereng & 3 \\
3 & Jarak Terhadap Sungai & 3 \\
4 & Batuan & 3 \\
5 & Penggunaan Lahan & 2 \\
6 & Jenis Tanah & 2 \\
7 & Permeabilitas Tanah & 2 \\
8 & Kedalaman Air Tanah & 1 \\
\hline
\end{tabular}

Tabel 10. Kelas Kesesuaian Lahan untuk Bangunan Candi

\begin{tabular}{ccc}
\hline Harkat Total & Kelas Kesesuaian Lahan & Simbol \\
\hline $40-55$ & Buruk & S3 \\
$56-71$ & Sedang & S2 \\
$>71$ & Baik & S1 \\
\hline
\end{tabular}

\section{KESIMPULAN}

1. Foto udara hitam putih dalam penelitian ini dapat mempelajari dan menyadap tiga dari delapan parameter karakteristik lahan untuk bangunan candi. Ketiga parameter tersebut adalah bentuklahan, penggunaan lahan dan jarak candi terhadap sungai, dimana ketiganya merupakan parameter yang dapat dengan mudah dipelajari dan disadap dibanding parameter lainnya. Kelima parameter lainnya diperoleh dari data sekunder yang merupakan hasil penelitian mengenai sumberdaya lahan yang pernah dilakukan di wilayah Prambanan.

2. Hasil interpretasi dari foto udara dan data sekunder tersebut dapat memperoleh parameter yang merupakan karakteristik lahan untuk kesesuaian lahan bangunan candi dengan analisis menggunakan perangkat analisis SIG sehingga dapat diperoleh peta satuan lahan dan selanjutnya dilakukan pengharkatan serta diberi pembobotan terhadap parameter-parameter tersebut hingga dapat memperoleh kelas kesesuaian lahan untuk bangunan candi di wilayah Prambanan.

3. Kelas kesesuaian lahan untuk bangunan candi di wilayah Prambanan terdiri atas Kelas S1, S2, dan S3. Lahan dengan kelas S1 adalah lahan yang memiliki kelas kesesuaian Baik untuk bangunan candi. Lahan kelas S2 adalah lahan yang memiliki kelas kesesuaian Sedang dan lahan dengan kelas S3 adalah lahan yang memiliki kelas kesesuaian Buruk. Hasil penelitian ini menunjukkan bahwa bangunan candi di wilayah Prambanan yang dibangun diatas lahan kelas S1 sebanyak sembilan candi dan sebanyak dua candi dibangun di atas lahan kelas S2. Tidak ada satupun bangunan candi yang dibangun diatas lahan kelas S3.

\section{DAFTAR PUSTAKA}

Acarya, Prasanna Kumar. (1934). Indian Architecture According to Manasara-Silpasastra. Manasara Series. Vol. II. London. Oxford University Press.

Banerjee, Manabendu. (1996). "Sanskrit Vastu-Works on Soil-Testing". Indian Journal of History of Science. 31 (3), 259-268.

Degroot, Veronique Myriam Yvonne. (2009). “Candi Space and Landscape: A Study on the Distribution, Orientation and Spatial Organization of Central Javanese Temple Remains". Disertation. Netherland. Leiden University.

Hardjowigeno, Sarwono. Widiatmaka. (2011). Evaluasi Kesesuaian Lahan dan Perencanaan Tataguna Lahan. Yogyakarta. Gadjah Mada University Press.

Kempers, A.J. Bernet. (1959). Ancient Indonesian Art. Cambridge, Massachusetts. Harvard University Press.

Lillesand, Thomas M. dan Ralph W Kiefer. (1998). 
Penginderaan Jauh dan Interpretasi Citra. Yogyakarta. Gadjah Mada University Press.

Mundardjito. (1993). "Pertimbangan Ekologis dalam Penempatan Situs Masa Hindu Budha di Daerah Yogyakarta : Kajian Arkeologi Ruang Skala Makro". Disertasi. Jakarta. Program Pasca Sarjana UI.

Slaczka, Anna. A. (2007). Temple Consecration Rituals in Ancient India. Leiden-Netherland. Brill.
Vardia, Shweta. (2008). "Building Science of Indian Temple Architecture”. Master's Thesis. Portugal. Universidade do Minho.

Zieler, Michael. (1999). Modelling Our World : The ESRI Guide to Geodatabase Design. New York. ESRI Inc. 